\title{
Mapping tree genera using discrete LiDAR and geometric tree metrics
}

\author{
Mapeo del género de árboles usando LiDAR y métricas geométricas para árboles
}

\author{
Connie Ko ${ }^{\text {a* }}$, Tarmo K Remmel ${ }^{\mathrm{b}}$ Gunho Sohn ${ }^{\mathrm{a}}$

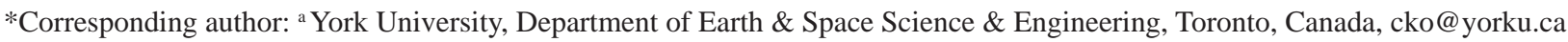 \\ b York University, Department of Geography, Toronto Canada.
}

\begin{abstract}
SUMMARY
Maps of tree genera are useful in applications including forest inventory, urban planning, and the maintenance of utility transmission line infrastructure. We present a case study of using high density airborne LiDAR data for tree genera mapping along the right of way (ROW) of a utility transmission line corridor. Our goal was to identify single trees that showed or posed potential threats to transmission line infrastructure. Using the three dimensional mapping capability of LiDAR, we derived tree metrics that are related to the geometry of the trees (tree forms). For example, the dominant growth direction of trees is useful in identifying trees that are leaning towards transmission lines. We also derived other geometric indices that are useful in determining tree genera; these metrics included their height, crown shape, size, and branching structures. Our pilot study was situated north of Thessalon, Ontario, Canada along a major utility corridor ROW and surrounding woodlots. The geometric features used for general classification could be categorized into five broad categories related to: 1) lines, 2) clusters, 3) volumes, 4) 3D buffers of points, and 5) overall tree shape that provide parameters as an input for the Random Forest classifier.
\end{abstract}

Key words: Airborne LiDAR, tree genera mapping, tree geometry, Random Forest Classification.

\section{RESUMEN}

Los mapas de géneros de árboles son útiles para el inventario forestal, planificación urbana y el mantenimiento de la infraestructura de líneas de transmisión. Se presenta un estudio de caso de uso de datos LiDAR de alta densidad para el mapeo de géneros de árboles a lo largo del derecho de paso (ROW) de un corredor de línea de transmisión. El objetivo de la investigación fue identificar árboles individuales que mostraban o poseían una amenaza potencial a la infraestructura de la línea de transmisión. Mediante el uso de mapas tridimensionales de LiDAR se derivaron métricas de árboles que están relacionadas con la geometría de éstos (formas del árbol). Por ejemplo, la dirección del crecimiento dominante de los árboles es útil para identificar árboles que crecen inclinados hacia las líneas de transmisión. También se derivaron otras métricas geométricas que son útiles para determinar los géneros de los árboles, tales como altura, forma de la copa, tamaño y estructura de ramas. El área de estudio se ubicó al norte de Thessalon, Ontario, Canadá, a lo largo de los principales corredores de ROW y en los bosques aledaños. Los atributos geométricos usados para la clasificación de los géneros fueron categorizados en cinco amplias clases: 1) líneas, 2) agrupamiento, 3) volúmenes, 4) amortiguamiento en 3D de puntos, y 5) forma general del árbol que provee parámetros como una entrada para el clasificador forestal aleatorio.

Palabras clave: LiDAR aéreo, mapeo de género de árboles, geometría de árbol, clasificación forestal aleatoria.

\section{INTRODUCTION}

Airborne light detection and ranging (LiDAR) has become a useful way of retrieving biophysical variables and for updating forest inventory maps. Tree genera or species information at an individual tree level is particularly useful in growth and yield estimates and have been studied primarily for forest applications such as updating forest inventories. In Holmgren and Persson (2004), the authors classified Norway spruce (Picea abies (L.) H. Karst.) and Scots pine (Pinus sylvestris L.) in Remningstorp Sweden. Ørka et al. (2007) classified spruce (Picea sp.), birch (Betula sp.) and aspen (Populus sp.) at Ostmarka natural forest in southern Norway and Suratno et al. (2009) classified ponderosa pine (Pinus ponderosa Douglas ex C. Lawson), Douglas-fir
(Pseudotsuga menziesii (Mirb.) Franco), western larch (Larix occidentalis Nutt.) and lodgepole pine (Pinus contorta Douglas) at the University of Montana's Lubrecht Experimental Forest near Missoula, Montana. Korpela et al. (2010) classified Scots pine, Norway spruce and birch by using intensity variables at Hyytiälä forest station in southern Finland. All these studies demonstrate the capability of using LiDAR for producing maps of tree species. When forested landscapes intersect with anthropogenic infrastructure, often complex monitoring and analysis are required; therefore, in addition to purely forestry applications, we would like to provide another use of tree genera mapping. We focus on electric transmission line ROW management and the identification of trees with the potential to cause power delivery disruptions by interfering with these transmission lines. 
The management of right of ways remain a challenge that utility company face, in particular, interruptions that are related to grow-in or fall-in vegetation that contribute to over $20 \%$ of total outages (Eckert 2004). The conventional right of way vegetation management in Ontario is based on a six or eight year cycle assessment involving crew visits or aerial inspections to determine if the utility transmission infrastructure has enough clearance from the vegetation. The inspection process is labour intensive, time consuming, and thus expensive. As a result, the use of LiDAR to map and manage right of way vegetation is becoming attractive because it can mitigate the inspection process (Ituen and Sohn 2010). In order to predict effective clearance zones and revisit periods, the identification of tree species growing in or near the right of way is important due to the different growth rates of different species. With proper genera (or species) data together with stem growth direction and tree-height data, growth and yield tables can be implemented to better estimate and predict the potential growth of the vegetation in or near a right of way. This is beneficial for determining the amount of cutting, trimming, or pruning that would yield a safe clearance zone around transmission lines and towers.

\section{METHODS}

LiDAR data was collected on 7 August 2009 north of Thessalon, Ontario, Canada, using a Riegl LMS-Q560 at an altitude of $140 \mathrm{~m}$ above ground level. The point density was approximately 40 pulses per $\mathrm{m}^{2}$. We surveyed 186 tree samples in the field, at eight different field sites measuring tree stem location, species, and diameter at breast height (DBH). Species collected include white birch (Betula papyrifera Marsh.), sugar maple (Acer saccharum Marsh.), red oak (Quercus rubra L.), jack pine (Pinus banksiana Lamb.), poplar (Populus tremuloides Michx.), white pine (Pinus strobus L.), white spruce (Picea glauca Moench
Voss), and larch (Larix laricina (Du Roi) K. Koch). Of the trees surveyed, 34 were maple, 67 pine, and 59 poplar, comprising the majority (160) of the 186 surveyed trees; we focus this work on these three genera.

The process of geometric feature extraction involves quantifying the geometric differences among the three genera of interest (figure 1).

The geometric features were classified into five categories and a qualitative description of each category is given in table 1 (equations and descriptions: appendix 1). For each tree, we isolated the tree crown from the rest of the tree by locating the height of the tree crown base and applied a height threshold.

These 24 features were used as input to the random forest classifier for genera classification; to validate the classification stability, we randomly split our sample trees into $30 \%$ for training and $70 \%$ for validation and repeated the classification 20 times. In addition to the 24 geometric features that we derived, for the purpose of right of way
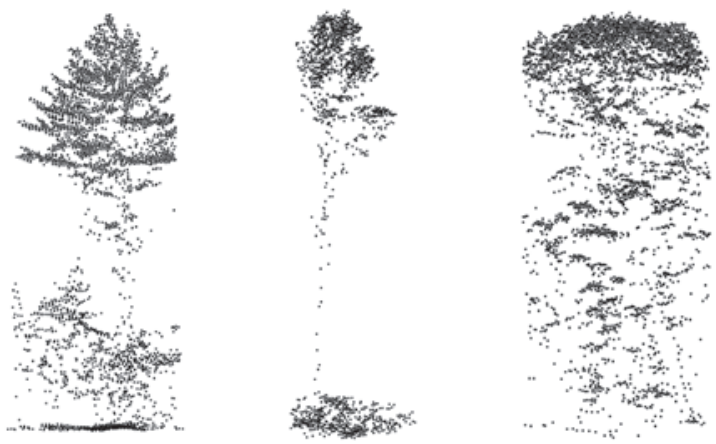

Figure 1. Sample trees from the genera Pinus (a), Populus (b), and Acer (c) respectively.

Árboles muestra del género Pinus (a), Populus (b) y Acer (c), respectivamente.

Table 1. Descriptive* summary for each geometric category.

Breve descripción* de cada categoría geométrica.

Linear (Internal):

Feature \# 1-5

Clusters (Internal):

Feature \# 6-10

Hulls (External):

Feature \# 11 - 17

Buffers (Internal):

Feature \# 18 - 21

Forms (External):

Feature \# 22 - 24
Characteristics of lines (lengths with respect to tree height, tree crown height, and_orientation angles) derived by grouping LiDAR points within the crown.

Characteristics of clusters (number of points, distances from each LiDAR point to the best fit lines and planes, volume of each cluster) within the crown.

Describe the form of the crown in terms of hulls (volume and the surface area of the convex hull or alpha shape for each crown, distance attributes calculated from each point to the closest facet of the convex hull).

Point distribution properties of the internal structure (proximal behaviors), each point is buffered outward in three dimensional space, volume and count of overlapping spheres are calculated.

Describe the overall shapes (ratio between radius of the crown to crown and tree heights, ratio between crown height and tree height).

* Equations and descriptions: appendix 1. 
mapping, we also computed the major growth direction of each tree to determine whether the tree is leaning towards or away from the utility transmission lines using a vertically sliding voxel to identify and connected point centroids within each trees' LiDAR point cloud to determine the approximate stem location and orientation.

\section{RESULTS}

For illustration, we included the results from using one example field site that involved the utility transmission line application. In this example, we demonstrated the capability of using LiDAR for mapping trees that showed potential threat. Figure 2A shows the LiDAR scene of the field site and the value (tone) of the points represented height above ground level $(\mathrm{m})$ and figure $2 \mathrm{~B}$ shows the location of the trees that we sampled in the area along the utility right of way, we surveyed 50 trees at this field site.
The utility transmission line at this site carries $230 \mathrm{kV}$, and according to the North American Electric Reliability Corporation (NERC) FAC-003-2 standard, this section of the transmission line would require a 50' (approximately $15.24 \mathrm{~m}$ ) minimum vegetation clearance distance (MVCD) zone. Therefore, a buffer zone of $15.42 \mathrm{~m}$ is extended from each side of the transmission line and we selected trees that intersect with the buffer zone. The polygons on figure 3 represent the maximal perimeter of each tree crown projected to the ground level. Within the set of trees that intersect with the buffer zone, we further selected the trees that are taller than $15.42 \mathrm{~m}$, indicating that if they fall, these trees may have the potential of contacting the utility infrastructure. Figure 3 shows the results of the tree boundaries that are mapped into three categories: 1) original tree boundaries 2) trees growing within MVCD, and 3) trees within MVCD and taller than $15.42 \mathrm{~m}$.
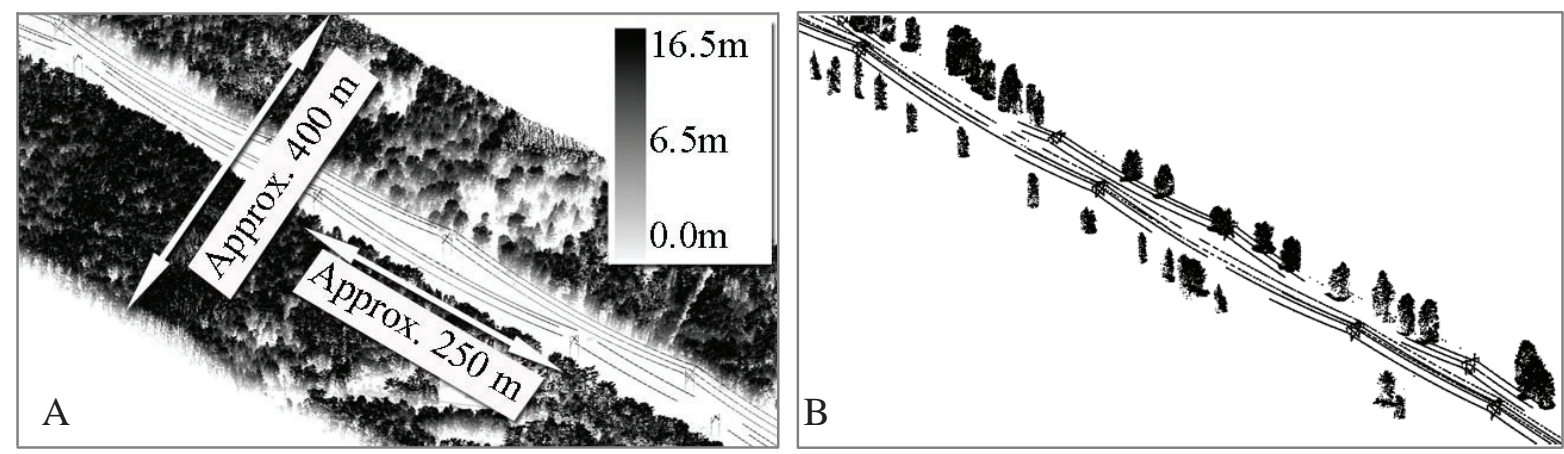

Figure 2. An oblique view of our LiDAR scene, height above ground level (A) and the locations of trees surveyed (B). Vista oblicua de la escena LiDAR para la altura sobre el suelo (A) y las ubicaciones de los árboles estudiados (B).

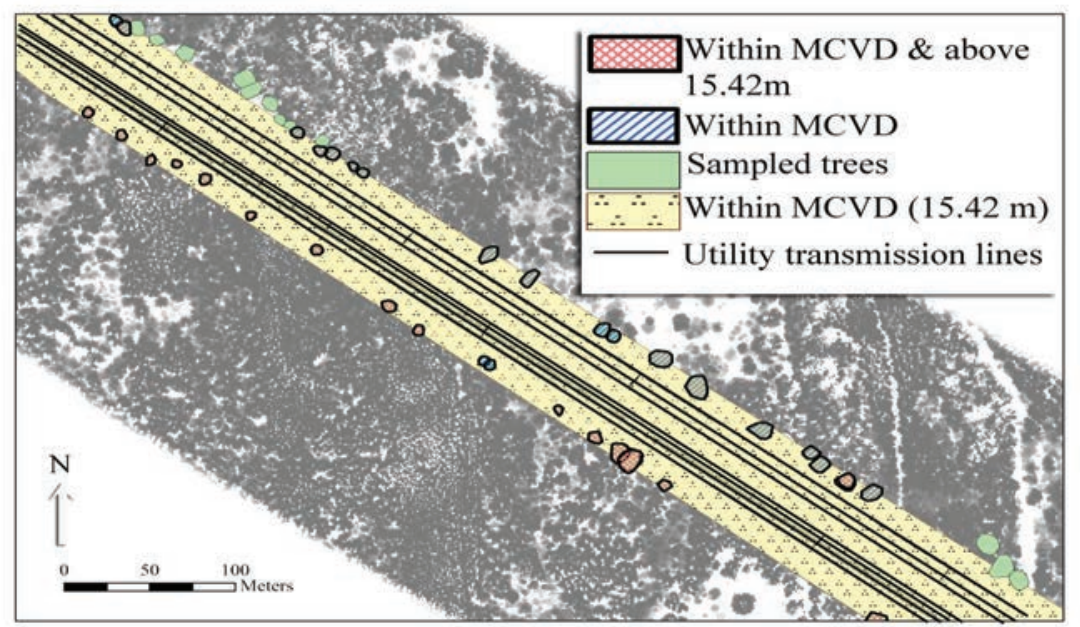

Figure 3. Map of tree crowns sampled along the ROW. Identified are the subset of trees that grow within the MVCD buffer zone, and further, those trees within the MVCD that are taller than $15.42 \mathrm{~m}$. Light grey represents LiDAR point cloud with trees of interest shown in colour.

Mapa de copas de árboles muestrados a lo largo de ROW. Se identificaron los subgrupos de árboles que crecen dentro de la zona de amortiguamiento de MVCD, y luego, los árboles dentro de MVCD que son más altos que 15,42 m. El gris claro representa nubes de puntos LiDAR con árboles de interés mostrado en color. 
The dominant growth direction of the tree can inform of the vertical angle of the tree, specifically toward a transmission line. Figure 4 shows the major growth direction of several example trees by connecting the centroids of a vertically moving voxel. The top centroid and the bottom centroid are connected to form a straight line as shown. The perpendicular distance from each tree top and tree bottom to the infrastructure is calculated, if the distance from the tree top to the infrastructure was smaller than the distance from the tree bottom to the infrastructure, then we defined the tree is leaning towards the infrastructure and these trees were flagged.

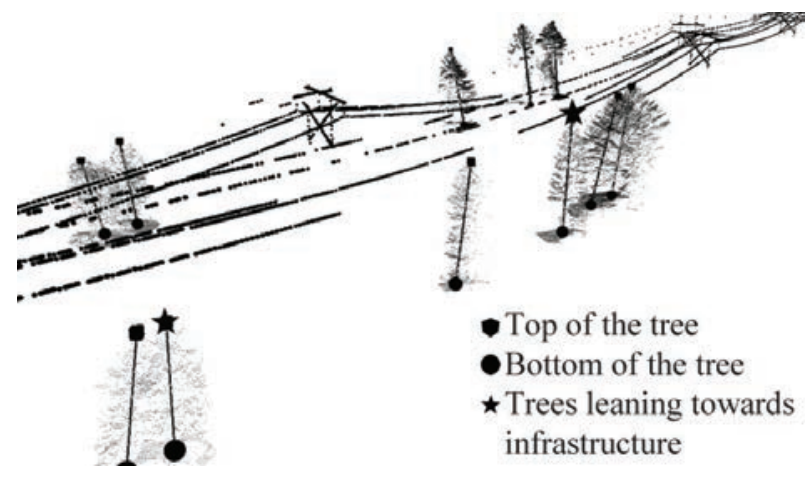

Figure 4. Example results showing the major growth direction of the sub-sampled trees. Straight lines are drawn by connecting the highest point within the tree to the lowest point within the tree.

Ejemplo de resultados que muestran la principal dirección de crecimiento de los árboles sub-muestreados. Las líneas derechas conectan el punto más alto del árbol con el punto más bajo de éste.
The genera classification results were added to the scene in the end; this additional information was useful to determine growth rate and time allowed utility companies to revisit the site for clearing the clearance zones. Figure 5 shows a map of tree boundaries with genera information, trees sampled in this field site only contain pines and poplar and therefore has no maples.

\section{DISCUSSION AND CONCLUSION}

In this paper we have presented a case study where LiDAR data can assist the mapping of vegetation along the utility ROW, we identify trees that are growing within the MVCD, and further recognize trees that are taller than the buffer distance meaning if the trees fall, it may potentially come in contact with the infrastructure. We then extend our knowledge by selecting trees that are leaning towards the infrastructure and include the genera information for better growth prediction. Although we have place an emphasis on tree genera classification, the information provided by the LiDAR can also yield additional attributes such as tree height, crown size and crown base height. The features input for Random Forest classification are related to the internal (clusters, lines and planes derived within the tree crown) and external geometry (overall shape of the tree crown) of the tree which makes our project unique from other studies that perform species or genera classification by using vertical profiling approach where features are derived from vertical point distribution attributes. The benefits of deriving features from geometric perspective are the close relationship between these features to tree forms which can be related to the biophysical interpreta-

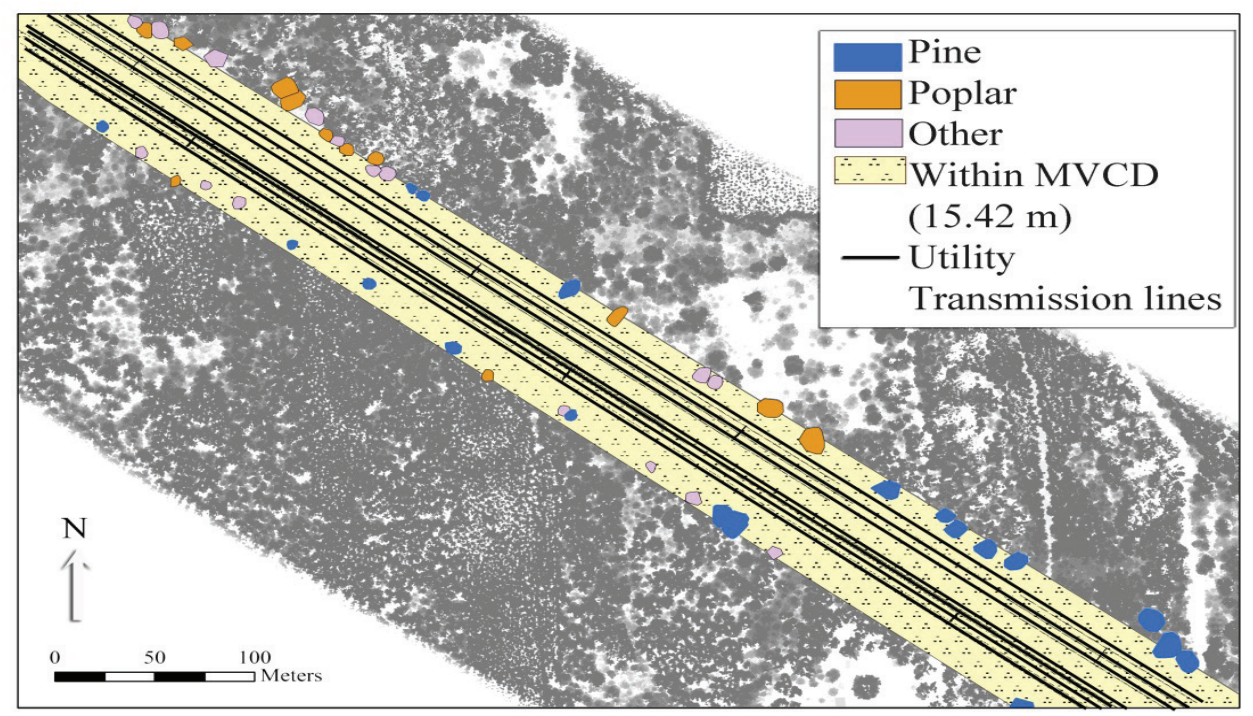

Figure 5. Map of tree boundaries with genera information. Light grey represents LiDAR point cloud with tree of interest showing in colour. Potential hazardous trees circled in red.

Mapa de límites de árboles con información de género. Gris claro representa nube de puntos de LiDAR y en color los árboles de interés. Árboles potencialmente peligrosos se muestran en círculos rojos. 
tion; it also yields better visual representations. The two approaches have its advantage and limitations and our current study suggest that they could be combined and provide supplementary information to form a stronger classifier, delivering a better accuracy (Ko et al. 2012).

\section{ACKNOWLEDGMENTS}

This research was funded by GeoDigital International Inc., Ontario Centres for Excellence, and a Discovery Grant from the Natural Sciences and Engineering Research Council of Canada.

\section{REFERENCES}

Eckert K. 2004. Proper tree and vegetation management makes major differences. Natural Gas Electricity 21(5): 1-8.

Holmgren J, Å Persson. 2004. Identifying species of individual trees using airborne laser scanning. Remote Sensing of Environment 90(4): 415-423.
Ituen I, G Sohn. 2010. The Way Forward: Advances in Maintaining Right-Of-Way of Transmission Lines. GEOMATICA 64(40): 451-462.

Ko C, G Sohn, TK Remmel. 2012. The impact of LiDAR point density on classifying tree genus: using geometric features and vertical profile features. In SilviLaser 2012, September 16-19, Vancouver, British Columbia, Canada. Proceedings. p. 67-75.

Korpela I, H O Ørka, M Maltamo, T Tokola. 2010. Tree species classification usingairborne LiDAR-Effects of stand and tree parameters, downsizing of training set, intensity normalization and sensor type. Silva Fennica 44(2): 319-339.

Ørka H O, E Næsset, O M Bollandsås. 2007. Utilizing airborne laser intensity for treespecies classification. International Archives of the Photogrammetry, Remote Sensing and Spatial Information Sciences 36: 300-304 Part 3/W52.

Suratno A, C Seielstad, L Queen. 2009. Tree species identification in mixed coniferous forest using airborne laser scanning. ISPRS Journal of Photogrammetry and Remote Sensing 64(6): 683-693. 


\section{Appendix 1.}

\begin{tabular}{lll}
\hline No. & Equation & Description \\
\hline F1 & $\frac{\sum_{n=1}^{k} L_{n}}{k \times H_{t}}$ & Average line segment lengths divided by tree height \\
F2 & $\frac{\sum_{n=1}^{k} L_{n}}{k \times H_{c}}$ & Average line segment lengths divided by crown height \\
F3 & $\frac{\sum_{n=1}^{k} L_{n}}{k} \times \frac{H_{c}}{H_{t}}$ & Average line segment lengths multiplied by the ratio between tree and crown heights \\
F4 & $\frac{\sum_{n=1}^{k} a_{x y n}}{k}$ & Average line segment angles (rad) measured from the x-y plane to the line \\
F5 & $\frac{\sum_{n=1}^{k} b_{x y n}}{k}$ & $\begin{array}{l}\text { Average line segment angles (rad) measured from the y axis to the line projected onto the } \\
\mathrm{x} \text {-y plane }\end{array}$
\end{tabular}

Where, $\mathrm{k}=$ number of clusters at the end of the clustering algorithm, $\mathrm{N}_{\mathrm{c}}=$ number of points in the crown, $\mathrm{L}_{\mathrm{n}}=$ length of the line in the cluster, $\mathrm{H}_{\mathrm{t}}=$ tree height, $\mathrm{H}_{\mathrm{c}}=$ tree crown height, $\mathrm{a}_{\mathrm{xy}}=$ angle between each line segment to xy plane, $\mathrm{b}_{\mathrm{xy}}=$ angle between the projected line to $\mathrm{y}$-axis.

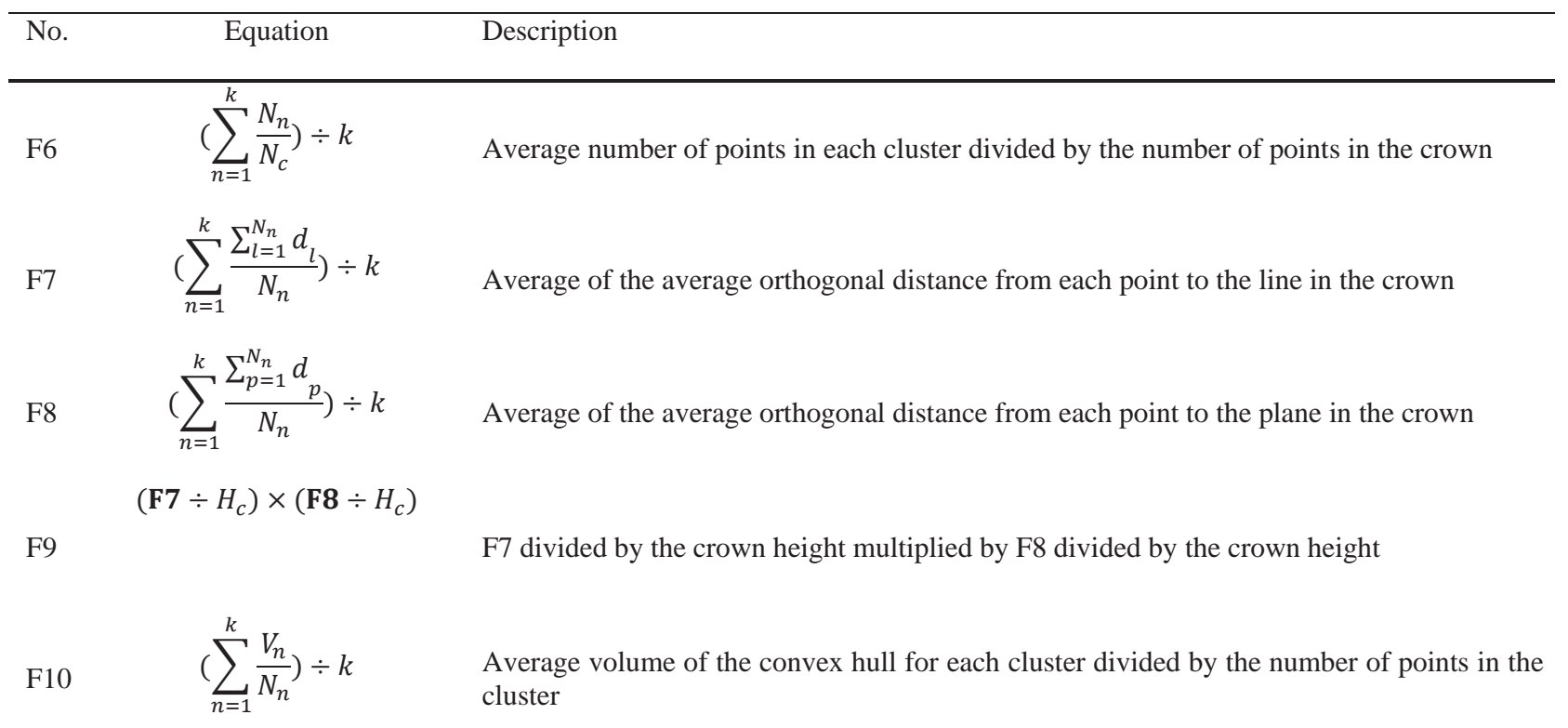

Where $\mathrm{N}_{\mathrm{c}}=$ number of points in the crown, $\mathrm{N}_{\mathrm{n}}=$ number of points in the cluster, $\mathrm{d}_{1}=$ orthogonal distance from each point to the line, $d_{p}=$ orthogonal distance from each point to the plane, $V_{n}=$ convex hull volume for cluster $n, N_{c}=$ number of points in the crown. 


\begin{tabular}{|c|c|c|}
\hline No. & Equation & Description \\
\hline F11 & $\frac{V_{h}-V_{a}}{V_{h}}$ & $\begin{array}{l}\text { Difference between the convex hull and alpha shape volumes compared to the } \\
\text { convex hull volume }\end{array}$ \\
\hline F12 & $\frac{A_{h}-A_{a}}{A_{h}}$ & $\begin{array}{l}\text { Difference between the convex hull and alpha shape areas compared to the convex } \\
\text { hull area }\end{array}$ \\
\hline F13 & $\frac{V_{h}}{N_{c}}$ & $\begin{array}{l}\text { Volume of the crown convex hull divided by the number of points within the } \\
\text { crown }\end{array}$ \\
\hline F14 & $\frac{V_{a}}{N_{c}}$ & $\begin{array}{l}\text { Volume of the tree crown alpha shape divided by the number of points within the } \\
\text { crown }\end{array}$ \\
\hline F15 & $\frac{\sum_{n=1}^{N_{c}} d_{h}}{N_{c}}$ & Average distance from each point to the closest facet of the convex hull \\
\hline F16 & $\sqrt{\frac{\sum_{n=1}^{N_{c}}\left(d_{h}-\mathbf{F 1 5}\right)^{2}}{N_{c}}}$ & Standard deviation of orthogonal distances from each point to the convex hull \\
\hline F17 & F15 $\div$ F16 & Coefficient of variation \\
\hline
\end{tabular}

Where $\mathrm{V}_{\mathrm{a}}$ = volume of the alpha shape of the tree crown, $\mathrm{V}_{\mathrm{h}}=$ volume of the convex hull of the tree crown, $\mathrm{A}_{\mathrm{a}}=$ area of the alpha shape of the tree crown, $A_{h}$ = area of the convex hull of the tree crown, $d_{h}=$ orthogonal distance form each point to the closest convex hull facet, $\mathrm{N}_{\mathrm{c}}=$ number of points in the crown.

\begin{tabular}{|c|c|c|}
\hline No. & Equation & Description \\
\hline F18 & $\sum_{i=N_{1}}^{N_{c}} \sum_{j=N_{1}}^{N_{c}} V_{i j}$ & Where $\mathrm{i} \neq \mathrm{j}$; sum of overlapped volume between $\mathrm{i}^{\text {th }}$ and $\mathrm{j}^{\text {th }}$ spheres \\
\hline F19 & $N_{i j}$ & Overlapped count of points captured by $\mathrm{i}^{\text {th }}$ and $\mathrm{j}^{\text {th }}$ spheres \\
\hline F20 & $\mathbf{F 1 8} \div N_{c}$ & Overlapped volume divided by the number of points within the crown \\
\hline F21 & $\mathbf{F 1 9} \div N_{C}^{2}$ & Count divided by the square of the number of points in the crown \\
\hline \multicolumn{3}{|c|}{ Where Vij = overlapped volume between $\mathrm{i}^{\text {th }}$ and $\mathrm{j}^{\text {th }}$ speheres, $\mathrm{N}_{\mathrm{ij}}=$ count of points captured by $\mathrm{i}^{\text {th }}$ and $\mathrm{j}^{\text {th }}$ spheres, $\mathrm{N}_{\mathrm{c}}=$ number of points in the crown. } \\
\hline No. & Equation & Description \\
\hline F22 & $H_{t} \div \sqrt{\frac{A_{x y}}{\pi}}$ & Tree height divided by the radius of the crown is circular when projected to $\mathrm{x}-\mathrm{y}$ plane \\
\hline F23 & $H_{c} \div \sqrt{\frac{A_{x y}}{\pi}}$ & Crown height divided by the radius of the crown is circular when projected to $\mathrm{x}-\mathrm{y}$ plane \\
\hline F24 & $\frac{H_{c}}{H_{t}}$ & Crown height divided by tree height \\
\hline
\end{tabular}

Where $\mathrm{A}_{\mathrm{xy}}=$ area of tree crown projected to $\mathrm{x}-\mathrm{y}$ plane 